\title{
EEN TWEEDE OOGST?
}

(Naar aanleiding van „Vruchten van de Reformatie”, door prof. G. van der Leeuw in 4 e jaargang, 2 en 3.)

Het is steeds een genoegen, een artikel van de theoloog Van der Leeuw te lezen, wanneer hij zich op cultuurhistorisch gebied begeeft. Zijn diepe kennis van aesthetische problemen waarborgt een goed gefundeerd oordeel en zijn grote belezenheid doet altijd originele vondsten verwachten. Zo ook nu weer in zijn studie over de vruchten der reformatie in het Nederlands cultuurleven van de 16e en 17e eeuw. Een mooi lied van Brederoo, een Christuskop van Rembrandt geven hem een fijne opmerking in de pen. Zijn schets van de wereldse orgelconcerten, gehouden veelal tegen de wens van de kerkeraad in, zal de Afrikaner menig kerkinterieur van onze oude meesters beter doen begrijpen.

Edoch - cultuur is meer dan kunst alleen! Vandaar dat de lezing van Van der Leeuws beschouwingen over de culturele vruchten der reformatie ons tenslotte onbevredigd laat. Met zijn gevolgtrekkingen over de invloed der Hervorming op artistiek gebied kunnen wij ons verenigen, ondanks zekere bezwaren, waarover aan het slot van dit artikel nader. Maar doordat Van der Leeuw grote gebieden van het Hollandse culturele leven buiten beschouwing laat, krijgen onze lezers een onvolledig beeld van de invloed die de Reformatie in Nederland heeft gehad.

Trouwens, ook de grezen die Van der Leeuw aan het begrip Reformatie zelf stelt, zijn niet duidelijk getrokken: enerzijds zegt hij, dat men

s1) op. cit. p. 292t. Vgl. Michaelis, a.a.O S.219f. 
eigenlijk niet nalaten kan, daaronder ook het catholizerende Kemonstrantisme, dat zich desondanks Gereformeerd noemt, te betrekken. Anderzijds gaat hij niet in op het reformatorisch element in een Hugo de Groot, van wie diens jongste biograaf, prof. Van Eysinga zo terecht zegt: , . . u uit het verhaal in her Parlalelon, hoe in ons land de Herrorming doorbrak, spreekt de overtuigde Protestant". ${ }^{1}$ )

Mar - keren wij terug tot ons uitgangspunt: Huizinga, die Van der Leeuw met voorliefde aanhaalt, vat de kultuur samen als de religieuze, morele, intellectuele en aesthetische waarden van een gemeenschap. Het is de tweede en derde groep nu, die de schrijver vrijwel geheel achterwege gelaten heeft. Terwijl juist daar de Calvinistische inslag het sterkst is in het geestelijke weefsel van het Nederlandse volk. Men denke eraan hoe het "reformatus quia reformandus" ertoe leidde, zoals Prof. J. Wr. Pont zegt, ,dat in de Hervorming naar voren komt wat men nieuwtestamentisch noemt het algemeen priesterschap der geloovigen, wat men ook noemen kan de betezkenis en het recht der persoonlijkheid". ${ }^{2}$ ) Teveel wordt vergeten, dat de Reformatie voor de ontwikkeling van dit individualisme in Nederland minstens even belangrijk is als Renaissance en Humanisme, en wel voornamelijk in haar Calvinistische vorm: ,het presbyterianisme in de kerk werkte de zelfstandigheid van het rolk tegenover de overheid in de hand" (Bavinck). ${ }^{3}$ ) Was het Calvinisme de leerschool, waarin vele der principes van de Nederlandse democratie zijn gevormd, het heeft in niet mindere mate de ontwikkeling van het Nederlands recht beïnvloed.

Het is hier niet de plaats om na te gaan wat het Romeins-Hollands recht aan de Reformatie te danken heeft, maar gewezen kan worden op het grotendeels in onbruik raken van het canonieke recht, waardoor nieuw recht, zoals het huwelijksrecht, moest worden geschapen, en op de reformatorische invloed in het nieuwe handels- en procesrecht. Ook denken wij an de grote invloed van gereformeerde commentatoren, zooals Paulus Merula, de achterneef van Angelus, Paulus Voet (zoon van Gysbert Voetius en fel bestrijder van het Cartesianisme), diens grote zoon Johannes Voet, Ulrick Huber en Cornelis ran Eijnkershoek, die jarenlang ouderling was in Den Haag.

Maar niet alleen de staats- en rechtsoprattingen, ook het natiebegrip zelf onderging de invloed van de reformatie: ,de Nederlandsche natie is als natie, in haar eenheid van godsdienst en taal, van karakter en zeden, uit de religie geboren; de Hervormde Kerk was het middelpunt en de kern van het Gemeenebest" (Barinck). Groen van Prinsterer gaat nog verder als hij zegt, dat de republiek is geboren uit de belijdenis der kerk.

1) W'. J. M. van Eysinga, Huigh de Groot, Haarlem 1945, p. 23.

") In „De Hervorming herdacht", Utrecht 1917, p. 44;

3) idem, p. 70. 
Ook op de sociale opvattingen van het Nederlandse volk heeft de Reformatie haar stempel gedrukt. Slotemaker de Bruine wijst op het fors organiseren van Calvijn in dit opzicht, in tegenstelling alweer met Luther; op de instelling van het diaconaat, waaraan reeds het convent van W'ezel in 1568 niet minder dan 19 artikelen wijdt, waaronder de eis van vrouwelijke diakenen; op het sociale werk van mannen als à Lasco en Bullinger; op deel IV, cap. 3, par. 9 in de Institutie van Calvijn. ${ }^{4}$ ) Wanneer de bedelorden en het bedelen zelf bestreden worden, weldadigheid niet meer tot zaligheid leidt, en armenzorg, om zich zelfs wil bedreven, de arme tot een nuttig lid der samenleving wil maken, komt vanzelf het probleem van de arbeid op de voorgrond.

Misschien heeft de Reformatie nergens dieper in ons culturele leven ingegrepen dan door haar eerherstel voor de ardse arbeid. ,Voor Luther is het beroep iets, dat de mensch als middel om in zijn levensonderhoud te roorzien, als goddelijke beschikking moet aanvaarden. Voor Calvijn evenwel is het een instrument om in de wereld tot verheerlijking van Gods naam werkzaam te zijn" (Diepenhorst). In het licht van deze laatste opvatting moeten wij de voortbrengselen van het Nederlands ambacht in de gouden eeuw zien, benevens de scheppingen van velen onzer kunstenaars.

Als de arbeid van de leek gelijksoortig gezien wordt met die van de priester, vervalt ook de Roomse depreciatie van het resultaat van die arbeid: het aardse bezit. Hoewel ons dit op een randgebied van het culturele leven brengt, willen we er toch een enkel woord van zeggen. Weinigen van ons delen thans nog de opvattingen over Reformatie en kapitalisme van Max Weber of Werner Sombart. Toch voerde in 1934 W. F. van Gunsteren weer een aantal overtuigende bewijzen aan, dat de calvinistische odgmatiek en ethiek tenminste het economisch individualisme heeft bevorderd. ${ }^{5}$ )

Hoe zou ooit de kolonisatorische arbied van het Nederlandse volk mogelijk zijn geweest zonder de opheffing van het Roomse renteverbod? „,Het verlossende woord werd gesproken door Calvijn, die die verouderde dwaalleer uiteenrafelde. Aan Lukas 6 vers 35 wordt de ware beteekenis teruggegeven" (Diepenhorst). Samengaand met de reformatorische waardering voor aards bezit is Calvijns bestrijding van de 16e eeuwse communistische leer der opheffing van het privaatbezit. „Hij heeft in een zijner schitterendste tractaten stuk voor stuk de onbijbelsche heweringen van hen, die goederengemeenschap door de H.S. geboden achtten, uiteengerafeld, den eigendom gebaseerd op den eenigen waren grondslag, op de heerschappij over het geschapene, die God den mensch verleend heeft, en daarmee een sterken dam tegen het wassend communisme

4) „De Hervorming herdache”, p. 108-110.

5) W. F. van Gunsteren, Kalvinismus und Kapitalismus. Amsterdam 1934. 
sopgeworpen." Prof. Diepenhorst, aan wie wij deze woorden ontlenen, zal hierbij wel doelen op Calvijns „Contre les Anabaptistes", dat bij Nederlandse geesten heel wat meer weerklank heeft gevonden dan Luthers hysterisch geschetter tegen $\mathrm{W}^{\prime}$ ederdo ers en Bozrenopstand.

Afgezien van de invloed der opheffing van het renteverbol op de Nederlandse kolonisatorische arbied, zou men trouwens met Huizinga kunnen zeggen, dat zonder het Calvinisme als ruggegraat en stuwende factor een der grootste culturele daden der gouden eeuw ongedaan gebleven zou zijn. Wij bedoelen de verspreiding dier Nederlandse cultuur - over het Verre Oosten en het Nieuwe Westen, over de Kaap zowel als over Nieuw Nederland. Zonder het Calvinisme zijn niet slechts een Coen, een Stuyvesant en een Van Riebeeck ondenkbaar, maar zou ook die onophoudelijke stroom van ongenoemden niet met zoreel succes zijn uitgegaan, waartoe reeds in de $17 \mathrm{e}$ eeuw ook Roosevelten en Smutsen behoorden, beiden van rechtgeaard Zeeuws en Gereformeerd geslacht.

Wij hebben in het voorafgaande geen critiek willen leveren of Prof. Van der Leeuw; wij hebben als het ware een ,tweede oogst" willen leveren, die gevoegd kan worden bij zijn ,vruchten van de Reformatie". Wij menen, dat een uitwerking van de thema's dezer tweede oogst door een andere hand dan die van Van der Leeuw in de ,Cultuurgeschiedenis van het Christendom" die Elsevier gaat publiceren, zal verschijnen. Daarom hebben wij het hier bij een aanduiding der thema's gelaten. Als niet, theoloog hebben we ons daarbij of uitspraken van theologen beroepenmet opzet nog al eens uit het symposium „De Herrorming herdacht”, waarin we protestantse vogels van diverse pluimage bijeenvonden. $\mathrm{Wij}_{\mathrm{ij}}$ wilden den lezers van dit tijdschift onze aanvullingen echter niet onthouden, omdat de artikelen van Van der Leeuws medewerkers niet hierin zullen verschijnen.

Tot slot nog enkele punten van directe critiek op Van der Leeuws inzichten over de reformatorische invloed op het artistieke leven.

Terecht noemt Van der Leeuw de volslagen saecularizatie van de schilderkunst de grootste verandering die met de Reformatic in het Nederlandse kunstleven optrad. Echter niet alleen "met", Joch ook „,door" de Reformatie. Als hij zegt: „De grootsche ontdekkingen van het binnenhuis, van het stilleven, van het landschap en het genrestuk geschieden ten koste van den Christelijken inhoud der vroege Nederlandsche kunst", dan zou men dat ook kunnen omkeren en zeggen: „,Doordat de Reformatie de Christelijke inhoud uit de schilderkunst bande, werd de weg gebaand voor de grootse ontdekkingen yan het binnenhuis, enz." En dan liever nog ,ontplooïngen” dan ,.ontdekkingen", want anders doet men den Vlaamsen en Noordnederlandsen Pimitieven onrecht. 
Constateren wij in de schilderkunst dus een negatiere werking van de Reformatie, in de bouwkunst zijn wij geneigd een sterker positieve werking aan te nemen dan Van der Leeuw doet, die geen specifieke protestantse kerkbouwkunst begint - afgezien van Willemstad (een vestingkerk!) - met het werk van Hiendrick de Keyser in Amsterdam. Deze kunstenaar, ,een sonderling liefhebber van 't vaderland, ende de godsdienst gantsch toegedaen", (volgens Salomon de Bray in de Architectura Moderna), heeft in de Zuider-en Westerkerk een ernstige poging gedaan om, voortbouwende op de oude traditie, een protestantse preekkerk te scheppen. Daarna heeft hij met de Noorderkerk - de eerste echte „Kruys-Kerck" in Nederland - een nieuw protestants kerktype geschapen, dat overal in den lande is nagevolgd. Nu geven wij Van der Leeuw gaarne toe, dat deze ,centraalbouw” is toegepast naar het model van de Italiaanse Renaissance. Maar is cultuur scheppen niet veelal het toepassen van nieuwe ideeën op het eigene? En bederft de herinnering aan de Santa Maria della Salute in Venetië voor Van der Leeuw zozeer het artistiek genot, dat de Marekerk te Leiden of de Nieuwe Kerk in 's Gravenhage, met hun eenvoudige, logische constructies, hem niet als protestantse kunst kunnen treffen? Tenslotte is ook nog de ,galerijkerk" een stuk protestantse bouwkunst, afkomstig als zij is van de Hugenotentempel van Charenton, al vinden wij deze vorm in Nederland roornamelijk in dissenterkerken.

Ook in Van der Leeuws bespreking van het calvinistisch element in de letterkunde menen wij tot een zekere mate een onderschatting van de invloed der reformatie te bespeuren. Men neme een figuur als Constantin Huygens, die in Van der Leeuws studie slechts voorkomt als de zeer hoog geschatte componist van monodische liederen, en als de schrijver ran "Gebruik of ongebruik van het orgel". Het blijkt, dat Van der Leeuw het criterium aanlegt of iemand dogmatisch aangelegd is of niet, om zijn mate van calvinisme vast te stellen. Van Cats zegt hij: ,... zeker niet de meest calvinistische, ... Jacob Cats was meer moralistisch dan dogmatisch aangelegd". Dit brengt het bezwaar mee, dat hij een goed Calvinist als Huygens inclerdaad niet als exponent van de reformatorische literatuur kan opnemen. En toch mis ik de Huygens van "Hofwyck" slechts node in zijn overzicht, ondanks het bekende "Staet uyt, Arminiaen . . En staet uyt, Gomarist", dat Huygens de strijders over de praedestinatie van zijn rustig buitenhuis af toeriep. Schreef hij niet:

„Wie kan de Christenen besien en niet beschreijen, „Die door Roomsch Misverstand van Sion zijn gescheijen, „En willen Scheppers zijn des Scheppers die haer schiep, „En willen noch voldoen 't gheen hij van 't Cruys af riep 
„By hem te zijn voldaen, en doen Hem stadigh sterven, ,Die ons door eene dood het leven heeft doen erven. ${ }^{6}$ )

Van der Leeuw heeft misschien uit het oog verloren, dat ,Huygens . . . een man uit een stuk . . . het vermogen (had) om ook het uiterlijk onverenigbare tot een harmonische samensmelting te brengen. $\mathrm{Hij}$ is Calvinist, maar loopt hoog met Erasmus; Marnix heeft zijn volle sympathie èn hij voelt veel voor de leer van de Stoa" (Prinsen). ${ }^{7}$ )

Van der Leeuw ziet in Nederland geen Calvinistische mannen van de wereld, typen als Clément Marot of Sir Philip Sydney. Vertegenwoordigt ridder Constatin Huygens niet de bezadigde Nederlandse vorm van dit type?

Marnix is anders, en toch heeft ook Van der Leeuw gevoeld, dat deze evenmin past bij het geijkte type van Dathenus en zijn kring. Maar waarom is Marnix weggelaten onder de dichters van het Calvinisme? Behoren zijn Psalmen Davids niet tot de schoonste uitingen van onze Reformatie? Is het $W^{\prime}$ ilhelmus - al of niet van Marnix - niet de calvinistische tijdzang bij uitnemendheid? Ja, is de ,tijdzang" zelf niet een van de meest kenmerkende uitingen van het Nederlands Calvinisme door alle eeuwen ran zijn bestaan? Om het even of we ,Bergen op Zoom" van Valerius horen, dan wel de ,Uitbreiding van den Tachtigsten Psalm, in 't rampjaar 1672" van Heiman Dullaert, de zang van Da Costa in 1848 of het lied van Muus Jacobse in de dagen der Duitse overheersing?

M. BOKHORST. 